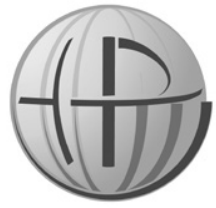

Horyzonty Polityki 2020, Vol. 11, No 34 OPEN ACCESS

\section{Mateusz Filary-Szczepanik}

http://orcid.org/0000-0001-9185-7904 Jesuit University Ignatianum in Krakow e-mail: m.z.filary@gmail.com

DOI: $10.35765 /$ HP. 1885

\section{Principle of economy of language and the question of anthropomorphism of state - A case of Okhams razor?}

Abstract

RESEARCH OBJECTIVE: The aim of the paper is twofold: (1) polemics with Alexander Wendt's thesis that state is a person and (2) innovative approach to the problem of anthropomorphism of state in general theories of International Relations.

THE RESEARCH PROBLEM AND METHODS: How is anthropomorphism of the state present in the language of grand theories of IR? How the language as a system shapes the phenomenon of anthropomorphism of the state in those?". Research methods: qualitative content analysis and close reading research technique

THE PROCESS OF ARGUMENTATION: Using these research method and techniques, the author analyses theories of Hans Morgenthau, Raymond Aron, Headley Bull, Morton Kaplan, and Kenneth Waltz seeking the presence of anthropomorphism as a feature of their language. He summarises his findings that enable him to critically engage with Alexander Wendt's thesis, hence fulfilling the scientific objective of the paper.

RESEARCH RESULTS: On the basis of the conducted research, the anthropomorphism of state is a fact of language of the analysed theories.

CONCLUSIONS, INNOVATIONS AND RECOMMENDATIONS: The author problematizes Alexander Wendt's thesis that state is a person by pointing out that anthropomorphism of state is not predicated upon the 
ontological reality of state as person, but on the linguistic rule that language seeks the economy of utterances. Pointing out to this fact is novel, since the literature referred in the article largely omits it. It is an important contribution for all the scholars for whom the problem of the state is a major research interest.

\section{KeYwORDS:}

International Relations Theory, State, Anthropomorphism, International Relations. State-Ontological Status

The idea of this article came to my mind when I was conducting workshops on group decision-making. They involved a simple simulation game - the participants played the roles of European Union policymakers and had to make a joint decision on the EU's approach to the mass influx of immigrants from Northern Africa and the Middle East. Each participant had a predefined number of votes, ability to influence others, and preferences regarding the way the immigration crisis should be handled. The proper decision-making simulation was preceded by a short lecture discussing the definition of state, the way it makes decisions on foreign policy, and the rules of decisionmaking simulation. I have noticed during the lecture that the more terms specific to international relations theory and foreign policy analysis I used to describe states, the less interested the audience was. But when I described states using expressions normally referring to human beings, i.e. stating that a given state may want, think, or do something, the audience paid more attention.

This occurrence led me to the debate sprung by Alexander Wendt and his ontological claim that the state is a proper person ${ }^{1}$ (Wendt $1999,2004,2005)$, as he argues that the wide spread of state's anthropomorphism in the discourse of IR is an indication of ontological reality of the state-person. This ontological claim was contested fiercely

1 The subject of state in International Relations is widely discussed in general terms in English literature - see for example: Waltz, 2001 [1959]; Wolfers 1962; Banks, Shaw, 1991; Ringmar, 1996; McCarthy, 1998, Lake, 2008, Krasner, 2009, Schuett, Stirk, 2015. In Polish literature, the problem of the state in International Relations in general terms was discussed among others in: Haliżak, Popiuk-Rysińska (ed.), 1995, Anioł, 2002, Kuźniar (ed.), 2005, Kłosowicz, (ed.), 2013; as well as on the margin of the reflection: Wojciuk., 2010, Pawluszko, 2014, Sadłocha, 2015. 
on the grounds of philosophical ontology - as pertinent to scientific ontology of IR on the grounds of ontological monism (Jackson 2004), scientific realism (Wight 2004) and general terms (Kaliher, Oprisko 2014). It was contested based on normative concerns about the consequences of treating state as a (biological) person (Neumann 2004, Lomas 2005), genealogical postmodern critique (Schiff 2008), critique challenging practicality of Wentian anthropomorphism on legalistic grounds (Kustermans 2011), or as a metaphorical device (Höne 2014). There are two interlocked problems with the above discussions. First, although some referred authors do mention the linguistic aspect of the state's ontological status, they do so either as a short mention about the usefulness of anthropomorphism of state for: 1) understanding or explaining social phenomena (Wight 2004, p. 56; Höne 2014, p. 12-14; Kaliher, Oprisko 2014, p. 44); 2) making the case that the state is a real person (Wendt 2004, p. 290-291, Wendt 2005, p. 359360 ) or they present it as a discursive metaphor that conveys but also distorts the meaning of social phenomena (Neumann 2004, p. 265; Schiff 2008, p. 371; Kustermans 2011, p. 2-3; Höne 2014, p. 89). None of them explains anthropomorphism of the state in the discourse of IR in strictly linguistic terms nor do they actually thoroughly analyse the phenomenon as it occurs in the texts of the discipline ${ }^{2}$, which is the second problem with the referred discussion.

To fill this gap in the literature, I want to answer to two research questions: "How is anthropomorphism of the state present in the classical grand theories of IR?" and "How the language as a system shapes the phenomenon of anthropomorphism of the state in those?" The first one will be answered using qualitative content analysis of the selected grand theories of IR with the term anthropomorphism operationalized on the basis of this category taken form the theory of literature. The second question will be answered with reference to the findings form the first question and the principle of the economy of the language.

2 With the excpetions beeing Neumann 2004, p. 60 and Höne 2014, p. 13-51 but still their analysis is lacking in depth as a general reconstruction without the proper examples from classical texts. The subject of metaphors present in the discourse of IR have been taken also by Marks 2011, 2018. 
In this context, anthropomorphism means attributing human features to the abstract notion of state. I will attempt to find out how classics of IR grand theory use it and what this usage tells us about the general conditions of the occurrence of the phenomenon. To properly operationalise the concept, it is worth quoting literary theory definition of this category: "humanising portrayal of phenomena of non-human world, as well as abstract creations of mind and imagination. Close to personification, it is less conventional in comparison, does not eliminate the proper nature of a phenomenon, does not transform it into a human being, but only attributes human traits, behaviours, and feelings to it" (Sławiński 1994, p. 18) ${ }^{3}$. Thus, in the analysed theories, I will have to reconstruct the theoretical meaning of the category of state, and compare it with the use of the word "state" elsewhere in the texts. The state will be considered anthropomorphised if the author of analysed theory attributes human traits to it even though he also gave it a concrete theoretical meaning.

As a method of presentation and interpretation supplementing the qualitative content analysis, I will use the so-called close reading from Anglo-Saxon literature studies, as it emphasises interpreting the text within the work itself without considering the textual reality outside it, at least on the first stage of the analysis. Close reading requires long quotations followed by interpretation. It allows reconstructing the interpreted author's thought without paraphrasing and partial quotations that may distort its meaning (Cieślak-Sokołowski 2012, p. 86-92)

The choice of works containing international relations theories has to be justified here. The subject of the analysis will be the works containing grand theories of international relations by Hans Morgenthau (1948), Morton Kaplan (1957), Raymond Aron (1962), Hedley Bull (1977), Kenneth Waltz (1979). Firstly, this choice allows presenting both classicists (Morgnethau, Aron, Bull) and behaviouralists (Kaplan, Waltz), or - generally - mainstream International Relations scholars form the "golden age" of grand international theory. Secondly, it allows discussing theories from both the United States (Morgenthau, Kaplan, Waltz) and Europe (Aron, Bull).

3 For the similar albeit more sparse definition from English literature see: Baldik 2001, p. 190. 
In Morgenthau's theory, the state is an organisation that acts as a set of norms channelling the individual lust of power of the citizens so that its execution is not a threat to their survival. At the same time, this individual lust of power is projected outwards, into international politics on the level of the entire community. In consequence, states not only aim at preserving their own existence, but also act aggressively in order to gain more power than they need to survive. State in Politics Among Nations is also a historically conditioned guarantor of moral standards inside the community it watches over: it aims not only at surviving as an organisation, but also at evolutionary development of the nation as a community of values (Filary-Szczepanik 2019, p. 250-255).

State's agency in Morgenthau's theory may also be considered the burden of statesman's ethics of responsibility. It is him, a great politician, who connects the singular and the community. Acting on behalf of his political community, he takes part in world politics as his state's avatar. State as a subject, object of theoretical reference, also has the components of national power that to some extent allow determining what it is (formation having these characteristics). Morgenthau considers them to be: geography, natural resources, industrial capacity, number and quality of citizens, military, preparedness, national character, morale of the society, quality of diplomacy, and efficiency of the government (Morgenthau 2006 [1948], p. 122-162).

An example of anthropomorphism of the stare in the language of Morgenthau's theory is the following quotation: "In view of their unsettled conflict over the status quo of Versailles, France translated the abstract ratio of equality into standards of actual armaments that were likely to perpetuate France's preponderance. On the other hand, Germany transformed the same ratio into concrete standards that, if effectuated, would have carried it to preponderance over France. Thus, France insisted upon its need for a larger army than Germany's because of the larger German population and its greater rate of increase. Germany countered by pointing to the superiority of France in trained reserves and to the large reserves of manpower and raw materials in the French colonial empire. Germany demanded a certain amount of artillery and airplanes because of its geographical 
position in the midst of potentially hostile nations. France denied that need by reminding the conference of its own special defense needs in view of its lack of natural strategic frontiers with Germany and of the fact that thrice within a century France had become the victim of German invasion." (Morgenthau 2006 [1948], p. 416).

The fragment contains theoretically structured elements, mostly national power components, and reference to interest, an important category for the theoretical construction of Politics, as state's characteristic. On the other hand, the states described in the above fragment are indeed anthropomorphised, in particular through the attribution of needs and actions such as refusing, requesting, etc. Thus, in Morgenthau's case anthropomorphism of the states is clearly present.

Aron treats and defines states as basic subjects of theoretical consideration of international political system. Relations between them form international relations that are the primary component of this system. This approach conceptualises the state very intuitively, defining it through its traits, ways of conducting foreign policy, and building international systems (Aron, 1995 [1962], p. 69-166). This concept is intuitive, because Aron does not precisely define the state (apart from traditionally considering it a Weberian independent, sovereign entity) or he seemingly assumes that the reader understands this term intuitively. The transition from the unitary to the community level, like in Morgenthau's case, uses two symbols of the state - soldier and diplomat. Basically, the avatars of the state are also used in Peace and War, although the normative level of this device, which in Morgenthau's work takes the form of statesman's ethics of responsibility, is much less visible (Aron, 1995 [1962], p. 17).

The relevant quotation reads the following:

Among the belligerents, one - state or bloc - is juridically criminal. What is the result of this "incrimination" of war that was once merely called unjust? Optimistically, let us suppose that the criminal state is defeated. How is it to be punished, and where are the criminals? Suppose we punish the state itself - in other words, amputate its territory, forbid it to arm, and deprive it of a share of its sovereignty. Now what matters most is that the clauses of the peace treaty prevent war's return: is it wise that the desire for punishment, however legitimate, should influence the treatment of the enemy and the clauses of the peace treaty? And we are considering, let us recall, the optimistic hypothesis. It is easy to imagine the use that the victorious Reich 
would have made of its right to punish the "criminal" states (Poland, France, Great Britain) (Aron, 1995 [1962], p. 153).

The above fragment is about international law, but it portrays states as criminals with all its consequences, which allows concluding that Aron too uses anthropomorphism. I would also like to stress that Bull's treatment of the state is not akin to the judicial person similar to the proposition made by Kustermans (Kustermans 2011, p. 2-3), but rather as a metaphor linked to the popular imagination of a person standing trial. Regardless, some theoretical aspects of Aron's category of state, such as sovereignty, territory, etc., are mentioned here, but anthropomorphism is present anyway, as he could have referred not to states themselves, but to their officials being punished.

Bull also understands the state rather intuitively. Although for Aron and Morgenthau the state is an important starting point for reflection, Bull's starting point may be interpreted as the order in social relations. Of course, he focuses on order in world politics, which is by default interpreted as the activity of states. In this concept, the state, apart from its traditional understanding in categories of an independent entity with some power and some interests, is categorised as a supplier of order for particular individuals in their relations inside it. This order is considered a situation in which the following objectives can be pursued in a given community (in fact, they make it a community): 1) protection of lives of community members; 2 ) guarantee of honouring the agreements concluded between community members; 3) ensuring that property rights are respected (Bull 2012 [1977], p. 3-23).

It is also worth emphasising that for Bull, like for Aron and Morgenthau, the transition from the unitary level (citizens) to state's agency as an actor of world politics (community level) is made through the indication that some citizens exercising certain political functions act on state's behalf as its avatars (Bull 2012 [1977], p. 63).

Let us now interpret a fragment of Bull's work:

The alternative to an international order in which the United States and the Soviet Union, or these two powers plus China, have a special stake may not be an order in which the rights of all states are equally provided for, but simply one in which these custodians and guarantors are replaced by others. 
In fact, the international order sustained by the great powers enjoys a wide measure of support throughout international society. The great powers do, however, have a permanent problem of securing and preserving the consent of other states to the special role they play in the system. Great powers can fulfil their manage-rial functions in international society only if these functions are accepted clearly enough by a large enough proportion of the society of states to command legitimacy (Bull 2012 [1977], p. 221).

What is interesting, anthropomorphism in the language of his theory seems to involve treating states like people forming a society, so we can speak of sociological reductionism here. ${ }^{4}$ Unlike in Wendt's case, I do not believe that for Bull the state is a real (in ontological sense) person. State is treated like a human in the sense that its actions in a community are a result of its perception in this community (whether it is authorised to take action), thus the above quotation seems to indicate that the anthropomorphism of state as a human being in a community is semi-deliberate but refers metaphorically to exactly that - human-in-the-community is a metaphor for state in international community.

For Kaplan, state is principally an entity the behaviour of which can be observed and generalised in order to explain and predict its actions. Kaplan uses theories that allow him to classify a given stateactor as having particular internal features. The problem here is the extent to which a state as an organisation follows its own rules and laws or - to the contrary - is subjected to the will of an individual or a small group that governs it at the moment, as well as balance in social sub-systems forming it (Kaplan 2005 [1957], p. 61-86). State is also characterised by capabilities, which however - understood substantially - are not the most important variable in Kaplan's theory (theoretical framework). He seems to focus rather on formal characteristics of systems, and capabilities play a role only when he writes about game theory (Kaplan 2005 [1957], p. 189-217). Despite this abundance of categories, Kaplan also anthropomorphises the state making it an analogue of human being and human behaviour in

4 In this case, reductionism is understood as reducing the explanations occurring in one discipline to the contents created within another one, considered more exact and better developed. More on the significance of the category of reductionism in: reductionism [in:] Honderich, 1995. 
behavioural psychology. However, it should not come as a surprise, given that Kaplan was one of the most prominent representatives of the behaviouralist approach. It does not undermine the fact that Kaplan also uses reductionism, this time psychologising (Filary 2010, p. 346-347).

Let menow examineKaplan's text and his useof anthropomorphism:

These rules [of the tight bipolar system - M.F-S.] undoubtedly will operate to increase dysfunctional tension between the bloc actors. Both blocs will approach the hierarchical or mixed hierarchical form. The leading national actors within the blocs will tend to have much closer control of policy objectives [of the entire bloc-M.F-S.] and will pay less attention to the demands and objectives of the non-leading national actors within the blocs. Since the rules for mixed or hierarchical blocs make the blocs highly incompatible, tension between the blocs will be great. Since the leading actors of these blocs will have greater control over bloc policy, the neglect of the domestic interests of non-leading bloc members will increase tension within the blocs (Kaplan 2005 [1957], p. 52).

Not only the specific language of systems theory and cybernetics is conspicuous, but also attributing actions such as paying or not paying attention, having requirements or control over something to states-actors. It leads us to the issue of anthropomorphism present, as it seems, in this fragment. Although the anthropomorphising reduction to behavioural psychology seems deliberate, its implementation is far from perfect - behavioural psychology studies behaviours, not inner states such as paying attention or having requirements. Also, what is evident is much greater care with which Kaplan uses his category of state if compared to the earlier presented examples. This difference should be obvious if we remember that Morgenthau, Aron and Bull represent the classical approach, whereas Kaplan is one of the main proponents of scientism in IR. Thus, in his somewhat tiring style, he is loyal to his own claims for proper explication, definition and rigorous usage of social scientific terms - state as actor in this instance. This interpretation of the difference between the style of earlier classics and Kaplan is important form the perspective of the economy of language it will turn to later.

In Waltz's theory, state is categorised as a "like unit". It means that for the purposes of his theory, states are identical in terms of aiming at 
preserving their existence. They are differentiated by capabilities, so mostly materialistically understood components of power. As such, state in his theory is a theoretical term constituting a useful fiction understood in nominalist terms. Its function is to allow the theory to explain, i.e. create laws that can be used to explain state's behaviour. Actually, there is only one law in Waltz's theory: states as like units, trying to survive in an anarchical international system, will present behaviours aiming at balancing the capabilities of other states. It is worth emphasising that the imagery of Waltz's thought is explicitly microeconomic - he consequently draws a parallel between state and firm or consumer on the market in the meaning of the neoclassical economic theory. Therefore, state is not reduced to a human being, but to a firm or consumer. However, it can be still considered a reduction, as explanation of international politics is reduced to the explanatory logic originating from economics (Guzzini, 1997; Filary-Szczepanik, 2019).

Let us examine anthropomorphism in the following fragment:

Some have hoped that changes in the awareness and purpose, in the organization and ideology, of states would change the quality of international life. Over the centuries states have changed in many ways, but the quality of international life has remained much the same. States may seek reasonable and worthy ends, but hey cannot figure out how to reach them. The problem is not in their stupidity or ill will, although one does not want to claim that those qualities are lacking. The depth of the difficulty is not understood until one realizes that intelligence and goodwill cannot discover and act on adequate programs. Early in this century Winston Churchill observed that the British-German naval race promised disaster and that Britain had no realistic choice other than to run it. States facing global problems are like individual consumers trapped by the "tyranny of small decisions." States, like consumers, can get out of the trap only by changing the structure of their field of activity (Waltz 1979, p. 110).

The anthropomorphism of state seems not only clear, but also deliberate. The transition between the level of individual and community remains problematic though. Waltz tries to avoid it in two ways. Firstly, using his metatheoretical assumptions: treating the state - the like unit - as a theoretical notion understood in nominalist terms without direct links to empirical reality, so ultimately 
unverifiable. Secondly, writing about particular international politicians as though they were undertaking certain actions. Although this stylistic device seems to pave the way to anthropomorphism of state in his theory, it is unjustified from the point of view of this very theory. Moreover, I could say that it brings it closer to classic realist theories with their statesman or diplomat as the avatar of state, which makes Waltz's statements regarding the properly scientific and exact nature of his theory problematic - he seems trapped between the need to use microeconomic language (for scientific legitimization of this theory), and traditional language of anthropomorphism (that he knows will convey the message he wants to send to the reader).

$* * *$

Anthropomorphism is indeed a feature of the language of the selected IR grand theories. Yet, contrary to the Wendt's claim that the its pervasiveness is a proof of its ontological status as a person, I would argue that the authors I analysed anthropomorphise out of convenience, not of ontological necessity. It is a practice understood and explained in the discipline for quite some time but sadly forgotten to large degree ${ }^{5}$ :

If nation-states are conceived of as the sole actors, it is inevitable that they be treated as if endowed, like human beings, with wills and minds of their own that permit them to reach decisions and to carry them out. Moreover, if state behavior is to be intelligible and to any degree predictable, states must be assumed to possess psychological traits of the kind known to the observer through introspection and through acquaintance with other human beings. States must be thought capable, for example, of desires and preferences, of satisfaction and dissatisfaction, of the choice of goals and means (Wolfers 1962, p. 10).

This is where the need, to explain - even roughly - this feature of the language of the discussed theories form the perspective of linguistics comes to the fore. Practically, we can cautiously attempt to explain it in two ways. Firstly, as a result of the economy principle of language. Secondly, reaching to the history of ideas. From the linguistic perspective, the economy of language, called the Zipf's law or

5 Qite the paradox being that the notable exception is Wendt himself Wendt 2004, p. 290-291. 
the law of least effort, states that the language aims at saving means used to communicate a given meaning. Simply put, the Zipf's law tells the sender: "speak in a way that allows you to communicate the maximum meaning using the minimum language content", and the recipient "choose the communicates you are able to understand with minimum effort" (Zipf 1948). If we accept this law at face value, we will understand, at least partially, both the anecdote opening this paper and the linguistic phenomenon (anthropomorphism) in the analysed texts. It also allows justifying deliberate usage of this device in scientific discourse when both the recipient and the sender is aware of it, when the term itself is properly defined at the beginning of the conversation. The quote from Wolfers also can be understood in new light from this perspective - the anthropomorphism of the state is a linguistic practice not only predicated upon the need to convey the message in the way the receiver would understand (and hence the attribution of the human qualities to the state, qualities the recipient knows from their own introspection and the communication of it to other like subjects capable of it), but also in the way that satisfies the economy principle. Simply put, if we, as IR scholars, communicated our findings about world politics with the constant use of our own theoretical notions of state, it would be a very lengthy and boring communication. Not only to the interested layman or decision-maker, but to ourselves as well. This, on the one hand, calls for explicit understanding of anthropomorphism as a fact of language we are using, on the other, it involves our careful consideration of what we are anthropomorphising in our everyday professional discourse - what meaning of the state we are using. I would claim that this is much more important than the answer to the philosophical question of the ontological status of the state, as presented in the opening of this article, or at least, that if one is determined to divulge in that question, it should not be without reference to the problem of economy of language - a gap that I hope I filled to an extent or at least made it known.

The second issue that may at least partially explain the phenomenon of anthropomorphism present in the analysed grand theories can be found not only in early modernity's political theory (Ringmar, 1996, p. 444-446), but also in earlier medieval European political thought (Szlachta 2013, p. 135-139). In this case, the prince is the connection between the individual subjects and their polity as a social whole - and 
if we consider the way classics' theories in one way or another use the avatar of the state in the person of the soldier, diplomat or a statesmen, we certainly see the history of this idea as something pertinent to the discourse on the political in the West for quite some time. From this perspective, the anomaly that is Kaplan's use of behavioural language when he theorises about the state is also quite telling. Him being one of the strongest proponents of the so-called scientific approach, form the perspective of history of ideas, comes from the tradition opposed to the holistic presentation of the state through its avatar - methodological and ontological individualism (Filary, 2010).

To a degree, we can decide which of these rough explanations is more satisfying. It may be achieved through similar case studies of theories created within the American analysis of foreign policy. Taking into consideration that this type of theories created within IR seems more distant from holistic inspiration, the presence of anthropomorphism in them would be in favour of the explanation based on the economy principle of language. A similar case could be also made if anthropomorphism were present in postmodern, gender, queer and critical literature of IR, as it is claimed that it is consciously clear of this phenomenon (Lomas 2005, p. 355). If it is the case in both instances, it would strongly corroborate the thesis that it is the language structuring its users toward the economy of their communication forcing them to anthropomorphise and not the "fact" that the state is a real person as Wendt claims it to be. Hence the Ockham's razor - instead of lofty philosophical debate about the personhood of the state, maybe let's just focus on precise and cogent usage of the language we have.

\section{BiBLIOGRAPHY}

Anioł, W. (2002). Państwo postsuwerenne? Rozproszenie władzy w środowisku międzynarodowym. Sprawy Międzynarodowe, no. 4, p. 5-26.

Aron, R. (1995) [1962]. Pokój i wojna między narodami. Warsaw: Centrum im. Adama Smitha.

Banks, M., Shaw, M. (1991). State and Society in International Relations. New York: Palgrave. 
Bull, H. (2012) [1977]. Anarchical Society: A Study of Order in World Politics. Basingstoke: Columbia University Press.

Cieślak-Sokołowski, T. (2012). Blisko tekstu - lektura krytyczna, dydaktyka uniwersytecka a teorie kulturowe. Edukacja, Vol. 118, no. 2.

Filary, M. (2010). Wybrane problemy metodologiczne II debaty w stosunkach międzynarodowych. Polilteja, Vol. 13, no. 1, p. 345-374.

Filary-Szczepanik, M. (2019). Anarchia i dyscyplina. Rzecz o realistycznych teoriach stosunków międzynarodowych Hansa Morgenthaua i Kennetha Waltza. Krakow: Wydawnictwo Naukowe Akademii Ignatianum w Krakowie.

Haliżak, E., Popiuk-Rysińska, I. (ed.) (1995). Państwo we wspótczesnych stosunkach międzynarodowych. Warsaw: ISM UW.

Honderich T. (ed.) (1995). The Oxford Companion to Philosophy. Oxford: Oxford University Press.

Höne, K.E. (2014). The State-as-Person in International Relations Theory, PhD thesis. Aberystwyth: Aberystwyth University, Department of International Politics.

Jackson, P.T. (2004). Hegel's House, or 'People Are States Too'. Review of International Studies, Vol. 30, no. 2, p. 281-287.

Kaliher, K., Oprisko, R. (2014). The State as a Person?: Anthropomorphic Personification vs. Concrete Durational Being. Journal of International and Global Studies, Vol. 6, no. 1, p. 31-49.

Kaplan, M. (2005) [1957]. System and Process in International Politics. Colchester: EPCR Press.

Kłosowicz, R. (2013). Pojęcie dysfunkcyjności państw - geneza i definicje. [in:] R. Kłosowicz (ed.), Państwa dysfunkcyjne i ich destabilizujący wpływ na stosunki międzynarodowe. Krakow: Wydawnictwo UJ.

Krasner, S. (2009). Power, the State, and Sovereignty: Essays on International Relations. London - New York: Routledge.

Kustermans, J. (2011), The state as citizen: state personhood and ideology. Journal of International Relations and Development, Vol. 14, p. 1-27.

Kuźniar, R. (ed.) (2005). Porzadek międzynarodowy u progu XXI wieku: wizje, koncepcje, paradygmaty. Warsaw: Wydawnictwo UW.

Lake, D. (2008). State and International Relations. [in:] C. Reus-Smit, D. Snidal, The Oxford Handbook of International Relations. Oxford: Oxford University Press.

Lomas, P. (2005). Anthropomorphism, personification and ethics: a reply to Alexander Wendt. Review of International Studies, p. 349-355.

Marks, P. (2011). The Role of Metaphors in International Relations Theory. New York: Palgrave.

Marks, P. (2018). Revisiting Metaphors in International Relations Theory. New York: Palgrave. 
McCarthy, L. (1998). Justice, the State and International Relations. London: Plagrave.

Morgenthau, H. (2006) [1948]. Politics Among Nations: The Struggle for Power and Peace. New York: McGraw-Hill.

Neumann, I.B. (2004). Beware of organicism: the narrative self of the state. Review of International Studies, Vol. 30, p. 259-267

Pawluszko, T. (2014). Kategoria systemu międzynarodowego w badaniach stosunków międzynarodowych. Toruń: Adam Marszałek Press.

Pietraś, M., Haliżak, E. (ed.) (2013). Poziomy analizy w nauce o stosunkach międzynarodowych. Warsaw: Rambler

Reus-Smit, C., Snidal, D. (2008). The Oxford Handbook of International Relations. Oxford: Oxford University Press.

Ringmar, E. (1996). On the Ontological Status of the State. European Journal of International Relations, Vol. 2(4), p. 439-466.

Sadłocha, J. (2015). Krytyczna analiza kategorii interesu w teorii stosunków międzynarodowych. Wrocław: Wydawnictwo UWr.

Schiff, J. (2008). 'Real'? As If! Critical Reflections on State Personhood, Review of International Studies, Vol. 34, no. 2, p. 363-377.

Schuett, R., Stirk, P. (2015). The Concept of the State in International Relations: Philosophy, Sovereignty and Cosmopolitanism. Edinburgh: Edinburgh University Press.

Sławiński, J. (1994). Podręczny stownik terminów literackich. Warsaw: Open.

Szlachta, B. (2013). Sprawiedliwość a racja stanu. [in:] A. Krzynówek-Arndt (ed.), Kryterium etyczne w koncepcji racji stanu. Krakow, p. $135-139$.

Waltz, K. (1979). Theory of International Politics. Boston: McGraw-Hill.

Waltz, K. (2001) [1959]. Man, the State and War. New York: Columbia University Press.

Wight, C. (2004). State agency: social action without human activity? Review of International Studies. Vol. 30, p. 269-280.

Wojciuk, A. (2010). Dylemat potęgi. Praktyczna teoria stosunków międzynarodowych. Warsaw: Wydawnictwo UW.

Wolfers, A. (1962) [1959]. Discord and collaboration - Actors in International Politics. Johns Hopkinss Press, Baltimore, p. 3-24.

Zipf, G. (1949). Human Behavior and the Principle of Least Effort. Cambridge: Mass.: Addison-Wesley.

\section{Copyright and License}

This article is published under the terms of the Creative Commons Attribution - NoDerivs (CC BY- ND 4.0) License http://creativecommons.org/licenses/by-nd/4.0/ 